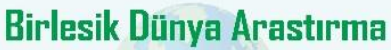 BD-CENTER \\ World Journal on Educational \\ Technology: Current Issues
}

Innovasyon ve Yayıneılık Merkezi

Volume 13, Issue 4, (2021) 651-671

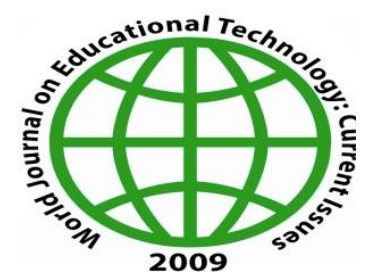

www.wj-et.eu

\section{Repercussions of Covid-19 crisis on students' remote learning in Saudi universities}

Norah Al-Qahtani ${ }^{\text {a }}$, King Saud University, Riyadh, Saudi Arabia, https://orcid.org/0000-0003-3901-295X

Wafa Abdullah Al-Salem ' ${ }^{\text {, }}$ King Saud University, Riyadh, Saudi Arabia, https://orcid.org/0000-0003-1846-9096

\section{Suggested Citation:}

Al-Qahtani, N., Al-Salem, W. (2021). Repercussions of Covid-19 crisis on students' remote learning in Saudi universities. World Journal on Educational Technology: Current Issues. 13(4), 651-671. https://doi.org/10.18844/wjet.v13i4.6251

Received from; July 03, 2021; revised from; August 15, 2021, accepted from; October 05,2021

Selection and peer review under responsibility of Prof. Dr. Servet Bayram, Yeditepe University, Turkey.

(C2021 Birlesik Dunya Yenilik Arastirma ve Yayincilik Merkezi. All rights reserved.

\begin{abstract}
This study aims to identify the positive and negative repercussions of the novel Coronavirus crisis on students' remote learning in Saudi universities. A descriptive survey method is carried out using a questionnaire and distributed to a cluster sample of 651 undergraduate students. Results reveal the most prominent positive repercussions, which are that the university cares about the learners' safety and health health and places them at the highest priority, review of recorded lectures and investing time. Results also reveal the most prominent negative repercussions, which are students' concern about their academic conditions, reduced access to teaching and research facilities and laboratories, and large assignments. Statistically significant differences are also found in favour of males, health disciplines, and King Faisal University and University of Hail.
\end{abstract}

Keywords: Repercussions,covid-19, student,remote learning,Saudi universities

* ADDRESS FOR CORRESPONDENCE: Norah Al-Qahtani, King Saud University, Riyadh, Saudi Arabia.

E -mail address: norahsq@ksu.edu.sa 


\section{Introduction}

We doubtless live in a world of rapid changes and face various challenges and evolutions, which together comprise real crises at the level of individuals, groups, organisations and countries (Al-Maghribi, 2019).

Crises pose a threat to human security and stability, creating hard conditions and necessities that require cooperation and concerted efforts, wisdom in controlling and directing such efforts, high skills in dealing with the crisis, and adequate infrastructure and organisation. Crises risks are increasing in scope, impact and in frequency in the current era (al-Bar, 2013).

According to Armstrong et al., (2020), the World Health Organization declared in the beginning of March, 2020, the novel Coronavirus (Covid-19) a global pandemic after its rapid spread around the world. In another press conference in Geneva, the organisation revealed that the Covid-19 is a common enemy, "a major global health crisis in the current era" (Al-Hurra Online Newspaper, 2020).

The Covid-19 pandemic is characterised as a global crisis, not only due to the geographic spread to all continents of the world, but also because the measures taken by governments and decision-makers to contain this disease have affected the daily lives of a broad range of people (Abu al-Khair, 2020).

Countries implemented various responses to the rapid and sudden changes caused by the Covid-19 crisis at the global, regional and local levels to limit the spread of the virus. These responses in turn have seriously affected different institutions of society (O'Hagan, 2020).

Amongst other responses, the measures require social distancing and the temporary closure of educational institutions. Higher education institutions around the world had to create distance learning opportunities for students to complete the academic year 2019-2020, and the first semester of the academic year 2020-2021. In fact, distance education has various potential benefits. Firstly, one session can contain a huge number of learners regardless of their geographical locations and students can efficiently interact with teachers and peers (Lin et al., 2021). Distance education increases the students' motivation to learn as they are visually stimulated by different instructional materials displayed through computer screens (Cho et al., 2021). On the other hand, various challenges may affect distance education. Examples are infrastructural challenges experienced by institutions, such as low budget, poor network connection, inefficiency of apparatus and devices, and old technological applications (Egielewa, et al., 2012).

Universities in the Kingdom of Saudi Arabia have not been spared these global changes, as the Ministry of Education (MOE) issued the Operational Plan for Universities to Combat Covid-19. This plan aims to take the necessary precautions to address Covid-19 and form a committee to manage this crisis at Saudi universities (SUs) (MOE, 2019, pp 11-12). The Ministry also emphasised the completion of an emergency plan to address the pandemic inside university facilities and the importance of initiative and coordination between institutions. The measures also stress the development of a national plan to deal with the crisis in its medical and social aspects, in addition to implementing an integrated awareness and educational plan for universities and the society (King Saud bin Abdulaziz University for Health Sciences).

\section{DEFINITION OF THE PROBLEM}

The Covid-19 pandemic has created the largest interruption of education in history, as learning institutions, including universities, have been closed. Traditional classroom teaching has shifted to 
online learning as a more suitable alternative to ensure the continuity of the educational process (AlKhati, 2020). UNESCO launched the Global Education Coalition to support countries in scaling up remote learning (RL), finding the best solutions, and trying to overcome obstacles to remote education (RE) (O'Hagan, 2020).

At the level of Arab countries, ALECSO launched the "Let's Learn" initiative, which aims to contribute to finding alternative technical solutions by taking advantage of technology as a response to the interruption of learning in physical institutions and to ensure the continuity of free education (ALECSO, 2020).

RE was successfully implemented in universities at the global, regional and local levels. The number of users for e-learning platforms also increased during the Covid-19 crisis. However, the sudden changes imposed-such as social distancing, universities closure and transition from traditional classroom teaching over to online learning-had repercussions on educational processes in general, and on higher education in particular.

The International Association of Universities (IAU) is closely monitoring the latest developments related to the impact of Covid-19 on universities around the world. In cooperation with the Erasmus Student Network (ESN), the IAU published a joint paper in two global survey reports, namely, 'Regional and National Perspectives on the Impact of Covid-19 on Higher Education' and 'The Impact of Covid-19 on Higher Education: Institutional and Students' Perspectives' (IAU, 2020).

The effects of the health crisis on higher education have occupied research attention in various disciplines and universities, whether at the global, regional or local levels. Studies carried out during the second semester of the academic year 2019-2020 and the first semester of the academic year 20202021 focused more on the impact of this crisis and its repercussions on RL and teaching in universities (Armstrong et al., 2020; Aristovnik et al., 2020; Bao, 2020; Brodeur et., al., 2020; Onyema et al., 2020; Sahu, 2020. However, no single study seems to elicit the views of undergraduate students about their online learning journey through the Covid-19 crisis in Saudi Arabia, even though their attitudes towards online learning are crucial to design study plans and adopt teaching strategies to cope with the changes and the great shift to online education. Such studies can show the opportunities and challenges that students face during these hard times to enhance their learning outcomes.

The main research question is: What are the repercussions of the Covid-19 crisis on students' RL in SUs? The following sub-questions are formulated.

Q1. What are the most prominent positive repercussions of the Covid-19 crisis on student RL in SUs?

Q2. What are the most prominent negative repercussions of the Covid-19 crisis on student RL in SUs?

Q3. Are statistically significant differences (SSD) caused by each of the following variables: gender, academic discipline and university?

This study examines the repercussions and impacts of the Covid-19 crisis on student RL in SUs. To the authors' knowledge, local studies rarely examine the effects of this crisis on male and female students in various disciplines and universities in all regions of the Kingdom of Saudi Arabia.

The authors hope that the study recommendations benefit decision-makers in improving how educational institutions can operate in the future, enhancing emergency RE and providing a supportive 
and stimulating environment for student learning through electronic platforms during and beyond the Covid-19 crisis. Thus, strategies that support student RL during any future epidemic can be developed.

The terms used in this study are as follows.

\section{Repercussions}

The Cambridge Dictionary defines 'repercussions' as the effects or consequences that may occur in the future. For the current study, 'repercussions' are the positive and negative effects of Covid-19 crisis on student RL in SUs.

\section{Crisis}

The historical origin of the term 'crisis' (крíøı=krisis) dates back to ancient Greek medicine, which means 'a turning point', denoting a sudden, fundamental change in the human body that may end in recovery or in death. This term soon moved from the field of medical sciences to various branches of knowledge and other social sciences, especially in education (Al-Yousifi, 2005).

The definitions include positive and negative repercussions of a crisis. Greene et al. (2000) defined crisis as the critical moment that determines a further negative or positive development of a situation, whilst Cooper (2007) views this as an opportunity to intervene, and a moment in which the outcome, whether good or bad, may be affected. Al-Shaalan (2013) provided the definition as a state of tension and a turning point that requires a decision that results in new situations, whether negative or positive, that affect the various entities involved.

In light of the previous definitions of crisis, this study summarises the definition of Covid-19 crisis in terms of its repercussions and effects on those affected, as a state of tension and a turning point that: threatens the well-being of individuals and interrupts the normal operations of the institution or its educational mission; affects the various related entities; requires a decision that results in new situations whether negative or positive; and causes a further negative or positive development.

\section{Conceptual THEORETICAL FRAMEWORK}

\section{Covid-19}

Covid-19 is a new strain of coronaviruses that appeared in the Chinese city of Wuhan at the end of December 2019 and continues to spread at present. The Ministry of Health $(\mathrm{MOH})$ reported the symptoms as those of acute pneumonia (MOH, 2019).

\section{Repercussions of the Covid-19 crisis on student RL in universities}

Witze (2020) indicated that Zwaan (former rector of Utrecht University in the Netherlands, and author of the book 'Global Threats and Opportunities: Higher Education in 2040. A Global Perspective') said, 'The pandemic is speeding up changes in a tremendous way'.

The sudden transition from traditional to emergency education via the Internet had positive and negative repercussions on student RL in universities. In this study, the positive repercussions are first discussed, followed by the negative ones.

\section{First: Positive repercussions}

In a virtual session that discussed the disruptions caused by the Covid-19 crisis, the measures taken since the beginning and the lessons learned, rectors of Washington University, Arizona State University and Purdue University agreed that all crises produce new ways of thinking. The rectors also 
agreed that Covid-19 has shed light on the importance of self-education, on-campus interaction, and students' personal interaction with faculty members and with each other. Universities are also inspired to serve their communities in new ways by undertaking Covid-19 testing efforts and making use of basic research and models in the fight against the virus (Frueh, 2020).

Quacquarelli Symonds (QS, 2020), a British company specialising in the analysis of higher education institutions around the world, has provided an ongoing survey of international students to understand their response to the global health emergency, Covid-19, and how that changes over time. This survey shows that students receive quick feedback, adequate advice and psychological support from faculty members, who are flexible in determining assignment deadlines and keen to maintain open lines of communication with students.

\section{Second: Negative repercussions}

In an attempt to analyse the expected immediate, medium and long-term impact of the emerging Covid-19 crisis on the different actors and the system as a whole, the UNESCO International Institute for Higher Education in Latin America and the Caribbean (IESALC) launched a report, which clearly shows that the situation is alarming for higher education students with vulnerable conditions. Under the pressure of the crisis, these students are more likely to drop out of education, and that forcing them to experience the unplanned dynamics of remote classes affect their daily lives and costs. In addition, the cessation of face-to-face teaching negatively affect students' ability to participate actively and effectively in their academic activities (IESALC, 2020).

\subsection{Related Research}

Brodeur et al. (2020) revealed the following findings: Improved academic achievement for students, especially low achievers; Good teachers' performance; Educational support from schools; and teachers and students have previous experiences of dealing with electronic learning platforms.

Sahu (2020) revealed that universities must implement measures to curb the prevalence of Covid-19, as follows: Students and their instructors should receive regular information via e-mails; the students and employees; safety should be main concerns; counselling services should be ensured to support the students; mental health and well-being ; and faculty members should master technology and care for student experiences to achieve rich and meaningful learning.

Armstrong et al. (2020) revealed that: Students preferred the synchronous style of RE, which is perceived to help keep them updated on lectures, motivates them, holds them accountable for their academic learning and provides them with increased time to complete assignments; Faculty support was available; Most students (64.5\%) indicated that the transition to online classroom increased their academic workload.

Bao (2020) focused on the state of RE in Peking University and concluded with five high-impact principles, as follows: Appropriate relevance between the teaching content and the academic readiness and online learners behaviour and characteristics; Effective delivery of teaching information; Sufficient support provided by faculty members to students; High-quality participation to improve the level of students' class participation; and Preparation of contingency plan for dealing with possible problems such as the traffic overload issue of the online education platform. Moreover, given that this remote teaching is implemented quickly during the outbreak of Covid-19, students' anxiety needs to be relieved in a positive way to ensure that they can actively and effectively engage in online education. 
IAU and ESN (2020) revealed a need to support students with a more holistic approach, not only at the academic level. Despite the majority of HEls having responded positively to the support provided to students, their lack of contingency plans can have a negative impact.

Onyema et al. (2020) revealed that the emerging Covid-19 has harmful effects on education, including learning disruptions, reduced access to educational and research facilities such as laboratories, weak infrastructure including network, power, inaccessibility issue and poor digital skills. The findings emphasise the devastating effects of Covid-19 on education.

Aristovnik et al. (2020) revealed that the teaching staff and universities' public relations provided students with the most important support during the outbreak of the pandemic. However, findings also revealed that the lack of computer skills and the view of a relatively high workload prevented students from achieving increased performance whilst adapting to the RL, the 'new normal'. In addition, during the closure, students mostly raised concerns about their future professional career and study issues. They were mainly bored, anxious and frustrated. However, the role of hospitals and universities appeared to be positive.

The above literature review shows that the current study is similar in addressing the impact of the Covid-19 crisis on universities, except for Brodeur et al. (2021) who focused on middle schools. However, the current study differs in terms of focusing on the repercussions of a crisis on undergraduate students' RL. To the authors' knowledge, the current study is one of the few that deals with identifying the most prominent positive and negative repercussions of Covid-19 on the RL of male and female students in various disciplines in five public universities in the Kingdom of Saudi Arabia. In its theoretical framework, the current study benefit from the tools, findings and recommendations from previous literature.

\section{METHODS AND MATERIALS}

\subsection{Research Model}

Given the nature and objectives of the current study, a descriptive survey is carried out.

\subsection{Participants}

The study population comprises all the undergraduate students in Saudi state universities for the academic year $1442 \mathrm{AH}$. Due to the large population size, the study participants are undergraduate students from four universities, as follows: King Saud University (KSU) (central region), King Faisal University (KFU) (eastern region), King Abdulaziz University (KAU) (western region), University of Hail (UH) (northern region) and King Khalid University (KKU) (southern region). These universities are selected as the representative population of SU undergraduate students in the five geographical regions. Amongst 470,809 students (taken from the MOE statistics for the year 2019), 242,427 are male and 228,382 are female. Table (1) shows the student distribution for each university, according to the MOE statistics.

Table (1) Distribution of participants in selected universities

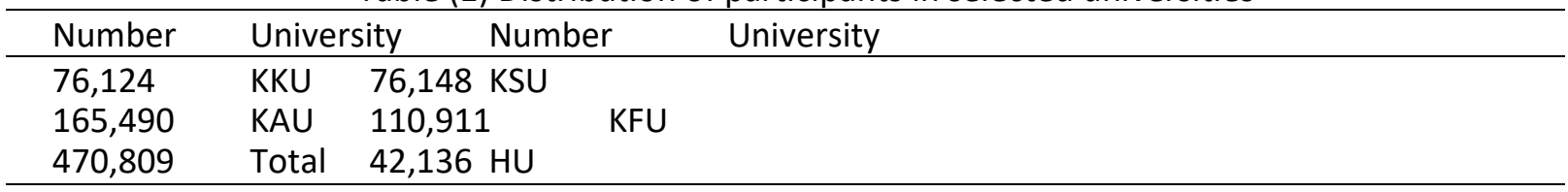


The sample size is 651 students, who are selected by cluster random method using the following website: http://www.raosoft.com/samplesize.html (Raosoft, 2004). Table (2) shows the student distribution according to study variables.

Table (2) Distribution of participants according to the study variables

\begin{tabular}{llll}
\hline Variables & Categories & Frequency & Percentage \\
\hline Gender & Male & 331 & 50.8 \\
& Female & 320 & 49.2 \\
Total & & 651 & $\mathbf{1 0 0 \%}$ \\
Academic & Health/Medical disciplines & 154 & 23.7 \\
Discipline & Scientific disciplines & 239 & 36.7 \\
& Humanitarian disciplines & 217 & 33.3 \\
Total & Community colleges & 41 & 6.3 \\
University & & 651 & $100 \%$ \\
& KSU & 149 & 22.9 \\
& KFU & 127 & 19.5 \\
& KKU & 133 & 20.4 \\
Total & KAU & 142 & 21.8 \\
& UH & 100 & 15.4 \\
\end{tabular}

Amongst the participants, 331(50.8\%) are males whilst $320(49.2 \%)$ are females. In terms of disciplines, 239 (36.7\%) are from scientific disciplines, 217 (33.3\%) are from humanities, 154 (23.7\%) are from health/medical disciplines and 41 (6.3\%) are from community colleges. In terms of university, 149 (22.9\%) are from KSU, 142 (21.8\%) are from KAU, 133 (20.4\%) are from KKU, 127 (19.5\%) are from KFU and $100(15.4 \%)$ are from $\mathrm{UH}$.

\subsection{Data collection tools}

In the current study, data are collected using a questionnaire that is designed on the basis of theoretical framework and relevant previous literature. In its final form, the questionnaire consists of two parts. The first part includes information on the study variables, which are gender, academic discipline and university.

The second part includes 44 phrases in the questionnaire, distributed on two axes:

1- Positive repercussion, (25) phrases

2- Negative repercussions, (19) phrases

The responses are designed according to a Likert-type Scale with five answers (Very Slightly Agree, Slightly Agree, Moderately Agree, Strongly Agree and Very Strongly Agree). The response scale ranges from 1-5, respectively.

For the purposes of analysis and estimation of sample responses, the following criterion is used: length of category = (maximum scale value - minimum scale value) / number of categories. The result is $(0.80)$, which is the length of the category. After that, this value is added to the minimum scale value that is (1) to start the scale grading, and thus the scale scores based on degree of agreement are as follows: Very strong (4.21-5.00); strong (3.41-4.20), moderate (2.61-3.40), slight (1.81 -2.60$)$ and very slight (1.00-1.80). 


\subsection{Data Collection Processes}

Validity of study tool

Validity is ensured by subjecting the tool to two types of tests, as follows.

a. Validity of arbitrators

The tool in its first form is submitted to a number of education specialist faculty members and those interested in higher education to seek their views on the clarity of each of questionnaire phrase, its importance and relevance to the axis to which it belongs. Benefiting from the suggestions of arbitrators, the deletion, amendment and addition for a number of phrases were made and the questionnaire is reformulated in its final form.

b. Internal consistency validity

The internal consistency validity of the questionnaire is examined using Pearson's correlation coefficient to determine the degree of correlation of each of the questionnaire phrases with the total degree of its axis. Table (3) shows the results.

Table (3): Pearson's correlation coefficients between the

\begin{tabular}{|c|c|c|c|c|c|c|c|}
\hline $\begin{array}{c}\text { Phrase } \\
\text { No. }\end{array}$ & $\begin{array}{l}\text { Correlation } \\
\text { coefficient }\end{array}$ & $\begin{array}{c}\text { Phrase } \\
\text { No. }\end{array}$ & $\begin{array}{l}\text { Correlation } \\
\text { coefficient }\end{array}$ & $\begin{array}{c}\text { Phrase } \\
\text { No. }\end{array}$ & $\begin{array}{c}\text { Correlation } \\
\text { coefficient }\end{array}$ & $\begin{array}{c}\text { Phrase } \\
\text { No. }\end{array}$ & $\begin{array}{l}\text { Correlation } \\
\text { coefficient }\end{array}$ \\
\hline 1 & $0.759 * *$ & 12 & $0.796 * *$ & 23 & $0.779 * *$ & 34 & $0.838 * *$ \\
\hline 2 & $0.845 * *$ & 13 & $0.785 * *$ & 24 & $0.869 * *$ & 35 & $0.614 * *$ \\
\hline 3 & $0.832 * *$ & 14 & $0.735 * *$ & 25 & $0.871 * *$ & 36 & $0.842 * *$ \\
\hline 4 & $0.758 * *$ & 15 & $0.826 * *$ & 26 & $0.834 * *$ & 37 & $0.878 * *$ \\
\hline 5 & $0.777^{* *}$ & 16 & $0.861 * *$ & 27 & $0.851 * *$ & 38 & $0.799 * *$ \\
\hline 6 & $0.821 * *$ & 17 & $0.866 * *$ & 28 & $0.832 * *$ & 39 & $0.843 * *$ \\
\hline 7 & $0.709 * *$ & 18 & $0.831 * *$ & 29 & $0.777 * *$ & 40 & $0.840 * *$ \\
\hline 8 & $0.670 * *$ & 19 & $0.862 * *$ & 30 & $0.725 * *$ & 41 & $0.846 * *$ \\
\hline 9 & $0.843 * *$ & 20 & $0.809 * *$ & 31 & $0.867 * *$ & 42 & $0.813 * *$ \\
\hline 10 & $0.796 * *$ & 21 & $0.806 * *$ & 32 & $0.845 * *$ & 43 & $0.791 * *$ \\
\hline 11 & $0.857 * *$ & 22 & $0.834 * *$ & 33 & $0.863 * *$ & 44 & $0.805 * *$ \\
\hline
\end{tabular}

Cleary, the values of the correlation coefficient of each of the phrases with its axis are positive, with statistical significance level at (0.01), which indicates the validity of the internal consistency amongst the questionnaire phrases and their relevance to their intended measurements.

Table (4): Pearson's correlation coefficients for the axes with the total score of the questionnaire

\begin{tabular}{lccc}
\hline Questionnaire axes & No. of Phrases & $\begin{array}{c}\text { Correlation } \\
\text { coefficient }\end{array}$ & $\begin{array}{c}\text { Statistical } \\
\text { significance }\end{array}$ \\
\hline First axis & 25 & $0.840^{* *}$ & 0.01 \\
Second axis & 19 & $0.750^{* *}$ & 0.01 \\
\hline
\end{tabular}


Frequenc

Agreement Degree

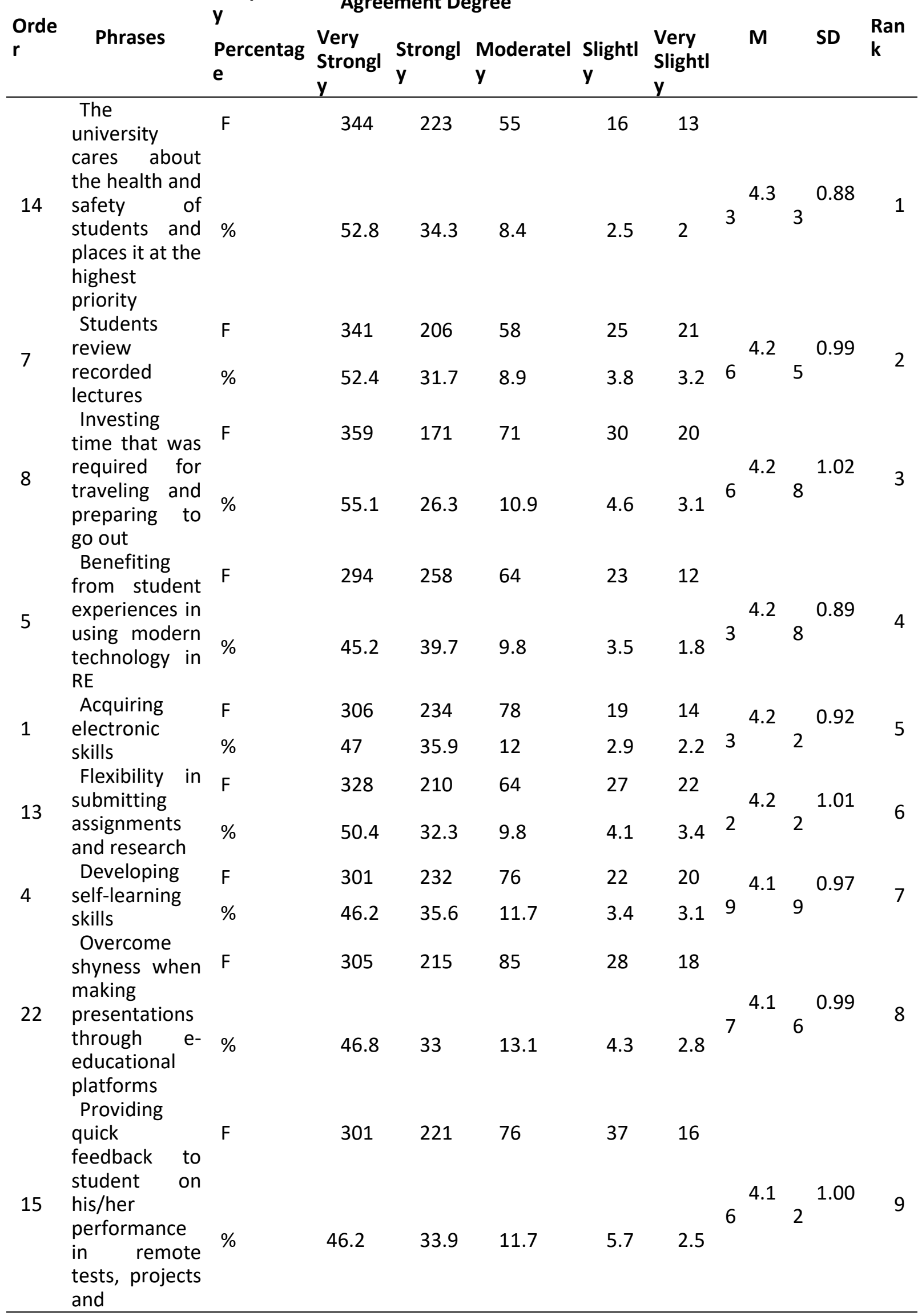




\begin{tabular}{|c|c|c|c|c|c|c|c|c|c|c|c|c|}
\hline \multirow{3}{*}{$\begin{array}{l}\text { Orde } \\
r\end{array}$} & \multirow{3}{*}{$\begin{array}{l}\text { Phrases } \\
\text { educational } \\
\text { tasks }\end{array}$} & \multirow{3}{*}{$\begin{array}{l}\text { Frequenc } \\
\text { y } \\
\text { Percentag } \\
\text { e }\end{array}$} & \multicolumn{3}{|c|}{ Agreement Degree } & \multirow{3}{*}{$\begin{array}{l}\text { Slightl } \\
y\end{array}$} & \multirow[b]{2}{*}{$\begin{array}{l}\text { Very } \\
\text { Slightl } \\
\text { y }\end{array}$} & \multirow{3}{*}{\multicolumn{2}{|c|}{$\mathbf{M}$}} & \multirow{3}{*}{\multicolumn{2}{|c|}{ SD }} & \multirow{3}{*}{$\begin{array}{l}\text { Ran } \\
\mathbf{k}\end{array}$} \\
\hline & & & $\begin{array}{l}\text { Very } \\
\text { Strongl } \\
\text { y }\end{array}$ & $\begin{array}{l}\text { Strongl } \\
\mathbf{y}\end{array}$ & $\begin{array}{l}\text { Moderatel } \\
\text { y }\end{array}$ & & & & & & & \\
\hline & & & & & & & & & & & & \\
\hline \multirow{2}{*}{23} & $\begin{array}{l}\text { Providing } \\
\text { Covid-19 }\end{array}$ & $\mathrm{F}$ & 304 & 211 & 92 & 21 & 23 & & 4.1 & & 1.01 & 1 \\
\hline & $\begin{array}{l}\text { prevention } \\
\text { guidelines }\end{array}$ & $\%$ & 46.7 & 32.5 & 14.1 & 3.2 & 3.5 & 6 & & 6 & & 0 \\
\hline \multirow{3}{*}{21} & $\begin{array}{l}\text { Using } \\
\text { alternative }\end{array}$ & $\mathrm{F}$ & 296 & 226 & 81 & 26 & 22 & & & & & \\
\hline & methods for & & & & & & & & 4.1 & & 1.01 & 1 \\
\hline & $\begin{array}{l}\text { evaluating } \\
\text { educational } \\
\text { assignments }\end{array}$ & $\%$ & 45.5 & 34.7 & 12.4 & 4 & 3.4 & 5 & & 1 & & 1 \\
\hline \multirow{2}{*}{20} & $\begin{array}{l}\text { Flexibility in } \\
\text { scheduling }\end{array}$ & $\mathrm{F}$ & 300 & 206 & 96 & 25 & 24 & & 4.1 & & 1.03 & 1 \\
\hline & $\begin{array}{l}\text { assessments } \\
\text { and tests }\end{array}$ & $\%$ & 46.2 & 31.6 & 14.7 & 3.8 & 3.7 & 3 & & 9 & & 2 \\
\hline \multirow[b]{2}{*}{17} & $\begin{array}{l}\text { Adopting an } \\
\text { evaluation }\end{array}$ & $\mathrm{F}$ & 289 & 229 & 78 & 30 & 25 & & & & & \\
\hline & $\begin{array}{l}\text { system } \\
\text { adequate to } \\
\mathrm{RE} \text { to use in } \\
\text { crises }\end{array}$ & $\%$ & 44.4 & 35.2 & 12 & 4.6 & 3.8 & 2 & 4.1 & & 1.04 & $3^{1}$ \\
\hline \multirow[b]{2}{*}{18} & $\begin{array}{l}\text { Students' } \\
\text { sharing the }\end{array}$ & $\mathrm{F}$ & 281 & 225 & 90 & 38 & 17 & & & & 1.01 & 1 \\
\hline & $\begin{array}{l}\text { enrichment } \\
\text { files for the e- } \\
\text { course }\end{array}$ & $\%$ & 43.2 & 34.6 & 13.8 & 5.8 & 2.6 & & 4.1 & 5 & 1.01 & 4 \\
\hline \multirow{3}{*}{24} & $\begin{array}{l}\text { Acquisition of } \\
\text { new skills in } \\
\text { areas of }\end{array}$ & $\mathrm{F}$ & 284 & 221 & 88 & 36 & 22 & & & & & \\
\hline & languages, & & & & & & & & 4.0 & & 1.04 & 1 \\
\hline & $\begin{array}{l}\text { artificial } \\
\text { intelligence } \\
\text { and creative } \\
\text { writing }\end{array}$ & $\%$ & 43.7 & 33.9 & 13.5 & 5.5 & 3.4 & 9 & & 4 & & 5 \\
\hline \multirow{3}{*}{22} & $\begin{array}{l}\text { Improved } \\
\text { academic }\end{array}$ & $\mathrm{F}$ & 295 & 213 & 79 & 37 & 27 & & & & & \\
\hline & achievement & & & & & & & & 4.0 & & 1.08 & 1 \\
\hline & $\begin{array}{l}\text { for low- } \\
\text { achieving } \\
\text { students }\end{array}$ & $\%$ & 45.4 & 32.7 & 12.1 & 5.7 & 4.1 & 9 & & 1 & & 6 \\
\hline \multirow{2}{*}{11} & $\begin{array}{l}\text { Developing } \\
\text { students' }\end{array}$ & $\mathrm{F}$ & 289 & 189 & 98 & 40 & 35 & & 4.0 & & 1.15 & 1 \\
\hline & $\begin{array}{l}\text { academic } \\
\text { performance }\end{array}$ & $\%$ & 44.4 & 29 & 15.1 & 6.1 & 5.4 & 1 & & 2 & & 7 \\
\hline
\end{tabular}




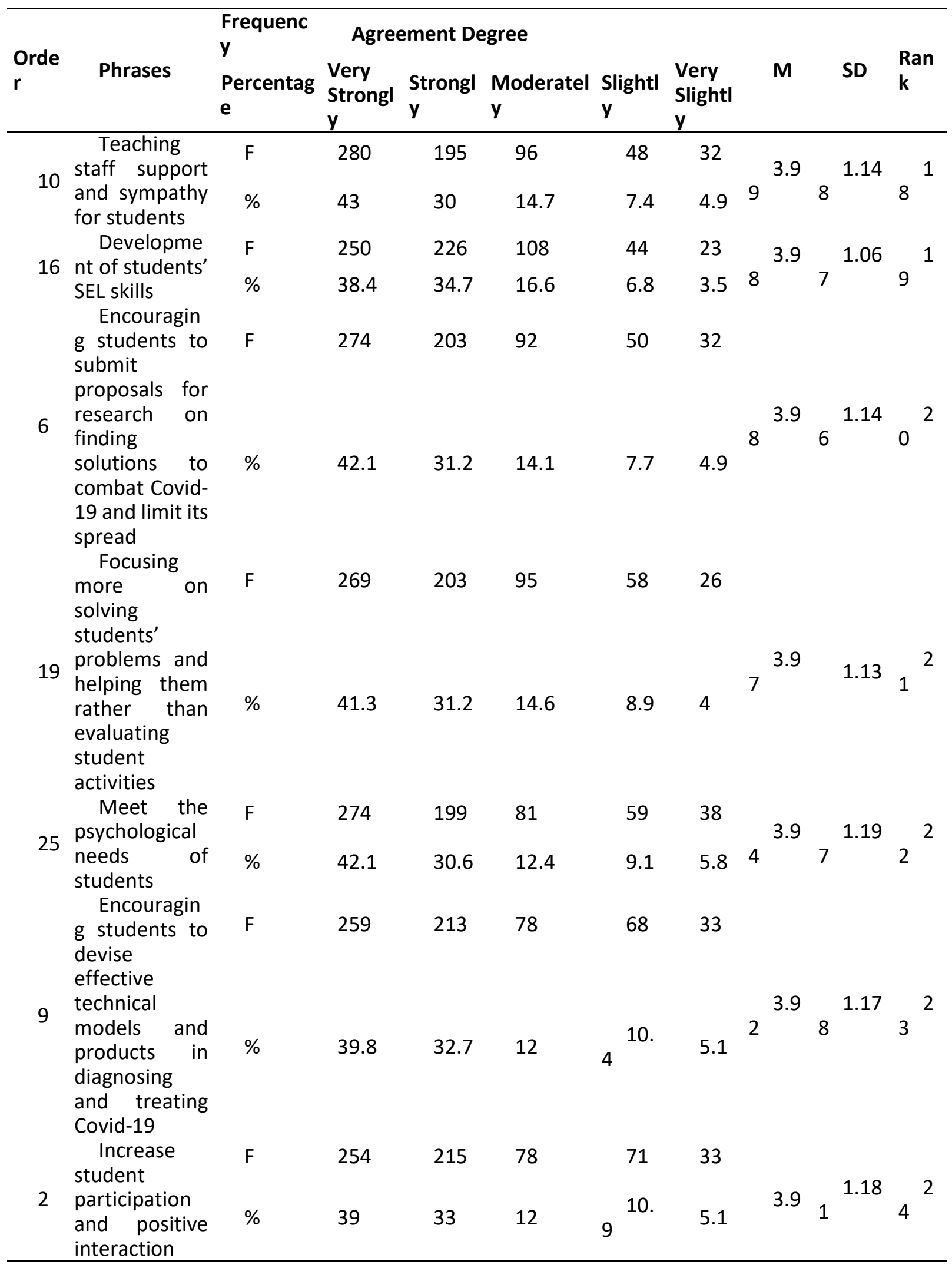




\begin{tabular}{|c|c|c|c|c|c|c|c|c|c|c|c|}
\hline \multirow[b]{2}{*}{$\begin{array}{l}\text { Orde } \\
r\end{array}$} & \multirow[b]{2}{*}{ Phrases } & \multirow{2}{*}{$\begin{array}{l}\text { Frequenc } \\
\text { y } \\
\text { Percentag } \\
\text { e }\end{array}$} & \multicolumn{3}{|c|}{ Agreement Degree } & \multirow[b]{2}{*}{$\begin{array}{l}\text { Slightl } \\
\text { y }\end{array}$} & \multirow[b]{2}{*}{$\begin{array}{l}\text { Very } \\
\text { Slightl } \\
y\end{array}$} & \multirow[b]{2}{*}{ M } & \multirow{2}{*}{\multicolumn{2}{|c|}{ SD }} & \multirow[b]{2}{*}{$\begin{array}{l}\text { Ran } \\
\mathbf{k}\end{array}$} \\
\hline & & & $\begin{array}{l}\text { Very } \\
\text { Strongl } \\
\text { y }\end{array}$ & $\begin{array}{l}\text { Strongl } \\
\mathbf{y}\end{array}$ & $\begin{array}{l}\text { Moderatel } \\
\text { y }\end{array}$ & & & & & & \\
\hline \multirow{3}{*}{3} & $\begin{array}{l}\quad \text { Raise the } \\
\text { level of } \\
\text { student }\end{array}$ & $\mathrm{F}$ & 262 & 172 & 70 & 73 & 74 & \multirow{2}{*}{$3^{3.7}$} & \multirow{2}{*}{\multicolumn{2}{|c|}{$3^{1.38}$}} & \multirow{3}{*}{$5^{2}$} \\
\hline & $\begin{array}{l}\text { understanding } \\
\text { and } \\
\text { comprehensio } \\
\mathrm{n}\end{array}$ & $\%$ & 40.2 & 26.4 & 10.8 & $2^{11 .}$ & $4^{11 .}$ & & & & \\
\hline & erall Average & & & & & & 4.09 & & & 0.861 & \\
\hline
\end{tabular}

Clearly, the values of the correlation coefficient of each axis is positive, with statistical significance level at (0.01), which indicates the validity of the internal consistency between the axes and their relevance to their intended measurements.

\begin{tabular}{|c|c|c|c|c|c|c|c|c|c|c|}
\hline & & & Agre€ & ement De & gree & & & & & \\
\hline $\begin{array}{l}\text { Orde } \\
r\end{array}$ & Phrases & Percentage & $\begin{array}{l}\text { Very } \\
\text { Strongl } \\
y\end{array}$ & $\begin{array}{l}\text { Strongl } \\
\mathbf{y}\end{array}$ & $\begin{array}{l}\text { Moderatel } \\
\text { y }\end{array}$ & $\begin{array}{l}\text { Slightl } \\
\mathrm{y}\end{array}$ & $\begin{array}{l}\text { Very } \\
\text { Slightl } \\
\text { y }\end{array}$ & $M$ & SD & $\begin{array}{l}\text { Ran } \\
\mathbf{k}\end{array}$ \\
\hline \multirow[b]{2}{*}{13} & $\begin{array}{l}\text { Student } \\
\text { concern about }\end{array}$ & $F$ & 317 & 206 & 72 & 41 & 15 & & \multirow[b]{2}{*}{1.013} & \multirow[b]{2}{*}{1} \\
\hline & $\begin{array}{l}\text { their } \\
\text { academic } \\
\text { conditions }\end{array}$ & $\%$ & 48.7 & 31.6 & 11.1 & 6.3 & 2.3 & $\begin{array}{l}4.1 \\
8\end{array}$ & & \\
\hline \multirow[b]{2}{*}{4} & $\begin{array}{l}\text { Reduced } \\
\text { access to }\end{array}$ & $F$ & 297 & 227 & 68 & 44 & 15 & \multirow[b]{2}{*}{$\begin{array}{l}4.1 \\
5\end{array}$} & \multirow[b]{2}{*}{1.009} & \multirow[b]{2}{*}{2} \\
\hline & $\begin{array}{l}\text { teaching and } \\
\text { research } \\
\text { facilities and } \\
\text { laboratories }\end{array}$ & $\%$ & 45.6 & 34.9 & 10.4 & 6.8 & 2.3 & & & \\
\hline \multirow[b]{2}{*}{5} & $\begin{array}{l}\text { Large } \\
\text { assignments }\end{array}$ & $\mathrm{F}$ & 327 & 186 & 62 & 50 & 26 & \multirow[b]{2}{*}{$\begin{array}{l}4.1 \\
3\end{array}$} & \multirow[b]{2}{*}{1.117} & \multirow[b]{2}{*}{3} \\
\hline & $\begin{array}{l}\text { due to raising } \\
\text { the semester } \\
\text { work mark to } \\
80 \%\end{array}$ & $\%$ & 50.2 & 28.6 & 9.5 & 7.7 & 4 & & & \\
\hline \multirow[b]{2}{*}{7} & $\begin{array}{l}\text { Low level of } \\
\text { student }\end{array}$ & $F$ & 302 & 200 & 71 & 55 & 23 & \multirow[b]{2}{*}{$\begin{array}{l}4.0 \\
8\end{array}$} & \multirow[b]{2}{*}{$\begin{array}{l}1.10 \\
7\end{array}$} & \multirow[b]{2}{*}{4} \\
\hline & $\begin{array}{l}\text { understanding } \\
\text { and } \\
\text { comprehensio } \\
\mathrm{n}\end{array}$ & $\%$ & 46.4 & 30.8 & 10.9 & 8.4 & 3.5 & & & \\
\hline \multirow{2}{*}{15} & \multirow{2}{*}{$\begin{array}{l}\text { Absence of } \\
\text { friendship }\end{array}$} & $\mathrm{F}$ & 289 & 204 & 78 & 56 & 24 & \multirow{2}{*}{$\begin{array}{l}4.0 \\
4\end{array}$} & \multirow{2}{*}{$\begin{array}{l}1.11 \\
3\end{array}$} & 5 \\
\hline & & $\%$ & 44.4 & 31.3 & 12 & 8.6 & 3.7 & & & \\
\hline
\end{tabular}




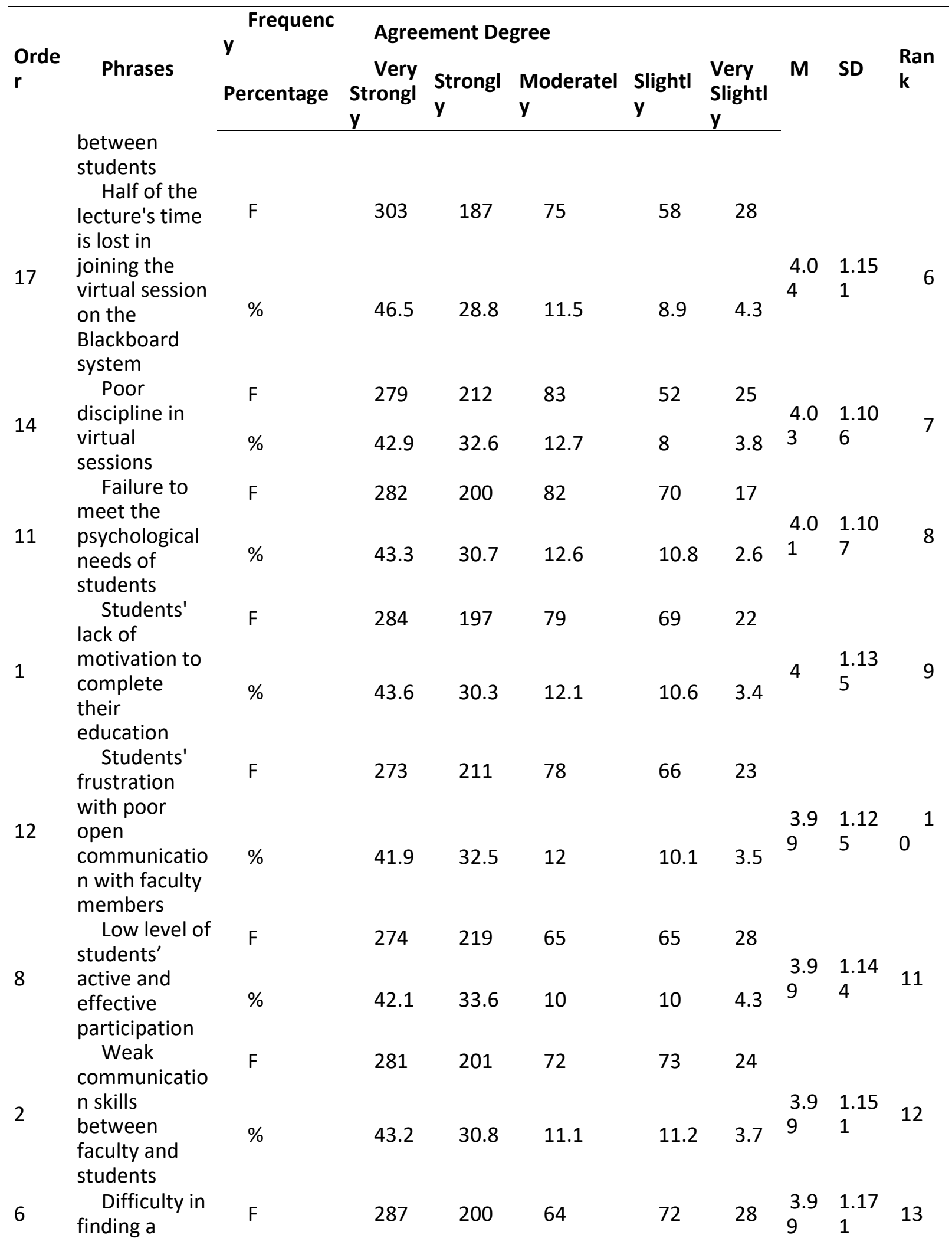




\begin{tabular}{|c|c|c|c|c|c|c|c|c|c|c|}
\hline \multirow{3}{*}{$\begin{array}{l}\text { Orde } \\
r\end{array}$} & \multirow{3}{*}{\begin{tabular}{l}
\multicolumn{1}{c}{ Phrases } \\
suitable \\
environment \\
for online \\
learning at \\
home
\end{tabular}} & \multirow{2}{*}{$\begin{array}{l}\text { Frequenc } \\
y \\
\text { Percentage }\end{array}$} & \multicolumn{7}{|c|}{ Agreement Degree } & \multirow{3}{*}{$\begin{array}{l}\text { Ran } \\
\mathbf{k}\end{array}$} \\
\hline & & & $\begin{array}{r}\text { Very } \\
\text { Strongl } \\
y\end{array}$ & $\begin{array}{l}\text { Strongl } \\
\mathbf{y}\end{array}$ & $\begin{array}{l}\text { Moderatel } \\
y\end{array}$ & $\begin{array}{l}\text { Slightl } \\
y\end{array}$ & $\begin{array}{l}\text { Very } \\
\text { Slightl } \\
y\end{array}$ & $\mathbf{M}$ & SD & \\
\hline & & $\%$ & 44.1 & 30.7 & 9.8 & 11.1 & 4.3 & & & \\
\hline \multirow{3}{*}{3} & Social & $\mathrm{F}$ & 262 & 219 & 85 & 63 & 22 & 3.9 & 1.10 & \multirow{2}{*}{14} \\
\hline & isolation & $\%$ & 40.2 & 33.6 & 13.1 & 9.7 & 3.4 & 8 & 7 & \\
\hline & $\begin{array}{l}\text { Difficulty in } \\
\text { using e- }\end{array}$ & $\mathrm{F}$ & 280 & 199 & 67 & 72 & 33 & & & \multirow[b]{2}{*}{15} \\
\hline \multirow[t]{2}{*}{19} & $\begin{array}{l}\text { learning } \\
\text { platforms via } \\
\text { mobile } \\
\text { phones }\end{array}$ & $\%$ & 43 & 30.5 & 10.3 & 11.1 & 5.1 & $\begin{array}{l}3.9 \\
5\end{array}$ & $\begin{array}{l}1.19 \\
7\end{array}$ & \\
\hline & $\begin{array}{l}\text { Insufficient } \\
\text { support }\end{array}$ & $\mathrm{F}$ & 276 & 183 & 95 & 72 & 25 & & & \multirow[b]{2}{*}{16} \\
\hline 9 & $\begin{array}{l}\text { provided by } \\
\text { faculty } \\
\text { members to } \\
\text { students }\end{array}$ & $\%$ & 42.4 & 28.1 & 14.6 & 11.1 & 3.8 & $\begin{array}{l}3.9 \\
4\end{array}$ & $\begin{array}{l}1.16 \\
5\end{array}$ & \\
\hline \multirow{2}{*}{10} & \multirow{2}{*}{$\begin{array}{c}\text { Tension } \\
\text { from Covid-19 }\end{array}$} & $\mathrm{F}$ & 257 & 208 & 85 & 72 & 29 & 3.9 & 1.16 & \multirow{2}{*}{17} \\
\hline & & $\%$ & 39.4 & 32 & 13 & 11.1 & 4.5 & 1 & 7 & \\
\hline \multirow[b]{2}{*}{16} & $\begin{array}{l}\text { Absence of } \\
\text { the spirit of }\end{array}$ & $\mathrm{F}$ & 271 & 194 & 76 & 78 & 32 & & & \multirow[b]{2}{*}{18} \\
\hline & $\begin{array}{l}\text { competition } \\
\text { between } \\
\text { students }\end{array}$ & $\%$ & 41.6 & 29.8 & 11.7 & 12 & 4.9 & $\begin{array}{l}3.9 \\
1\end{array}$ & $\begin{array}{l}1.20 \\
4\end{array}$ & \\
\hline \multirow[b]{2}{*}{18} & Withdrawal & $\mathrm{F}$ & 221 & 173 & 96 & 107 & 54 & 3.6 & 1.32 & \multirow[b]{2}{*}{19} \\
\hline & $\begin{array}{l}\text { from the } \\
\text { semester }\end{array}$ & $\%$ & 33.9 & 26.7 & 14.7 & 16.4 & 8.3 & 1 & 1 & \\
\hline \multicolumn{6}{|c|}{ Overall Average } & \multicolumn{3}{|c|}{4.00} & \multicolumn{2}{|c|}{0.928} \\
\hline
\end{tabular}

Consistency of study tool

The study tool consistency is verified by the Cronbach's Alpha ( $\alpha$ ) stability coefficient. Table 5 shows the results for each axis of the questionnaire.

Table (5) Cronbach's alpha coefficient to measure the tool consistency

\begin{tabular}{lll}
\hline Questionnaire axes & No. of Phrases & Consistency \\
\hline First axis & 25 & 0.978 \\
Second axis & 19 & 0.972 \\
Overall Consistency & $\mathbf{4 4}$ & $\mathbf{0 . 9 6 8}$ \\
\hline
\end{tabular}

Table (5) shows that the overall consistency is high, reaching (0.968), which indicates that the questionnaire has a high degree of stability, and therefore can be relied upon in the field application of the study. 


\subsection{Data Analysis}

Descriptive statistics were used to identify the participants' views towards the variables investigated in the current study. Inferential statistics were also run to find out differences among the participants

that could be ascribed to some demographic variables such as gender, academic disciplines, and institutions. All the statistical significance level was calculated at .05.

\section{RESULTS}

Table (6) shows the results related to the first question, which reads 'What are the positive repercussions of the Covid-19 crisis on students' RL in SUs from students' viewpoint?'.

Table (6) Participant responses to the positive repercussions of the Covid-19 crisis, in descending order according to agreement percentages

The results clearly show that the overall average value of the participants' responses to the first axis's phrases is 4.09 (out of 5.00), in the fourth category of the 5-point scale (from 3.41 to 4.20).

Table (7) shows the results related to the second question, which reads 'What are the most prominent negative repercussions of the Covid-19 crisis on student RL in SUs from the students' viewpoint?'. Table (7) Participant responses to the negative repercussions of Covid-19 crisis arranged in descending order according to the agreement percentages

Table (7) Participant responses to the negative repercussions of Covid-19 crisis arranged in descending order according to the agreement percentages

A review of the results in Table (7) clearly shows that the overall average value is (4.00), which falls within the fourth category of the 5-point scale (3.41-4.20) (Strong Degree of Agreement), which indicates that the students of SUs are strongly agreeing with the negative repercussions of the Covid-19 crisis on their RL.

Results of the third question, 'Are SSDs observed in the participants' responses to the study's research questions due to each of the following variables: gender, academic discipline and university?' are shown below. 
First: Differences according to Gender

Table (8) T-test for the differences in the participant responses due to Gender

\begin{tabular}{lllllllll}
\hline Axes & Gender & Frequency & Mean & SD & T-test & DF & Sig. & \\
\hline \multirow{2}{*}{ First axis } & Male & 331 & 4.29 & 0.778 & \multirow{2}{*}{6.201} & 649 & \multirow{2}{*}{$0.000 *$} & Sign. \\
& Female & 320 & 3.88 & 0.893 & & & 0.001 & \\
\multirow{2}{*}{ Second axis } & Male & 331 & 4.11 & 0.949 & \multirow{2}{*}{ Sign. } \\
& Female & 320 & 3.88 & 0.891 & 649 & $* *$ & \\
\end{tabular}

The results in Table (8) clearly show SSDs in the participant responses at (0.01) level according to different 'gender' variables, in favour of males.

Second: Differences according to Academic Discipline

Table (9) Results of one-way ANOVA for the differences in participant responses due to Academic

\begin{tabular}{|c|c|c|c|c|c|c|c|}
\hline \multicolumn{8}{|c|}{ Discipline } \\
\hline Axes & Source of variation & SS & DF & MS & F Value & Sig. & \\
\hline \multirow{3}{*}{ First axis } & Between-group & 3.202 & 3 & 1.067 & \multirow{2}{*}{1.444} & \multirow{2}{*}{0.229} & \multirow{2}{*}{ No Sign } \\
\hline & Within-group & 478.230 & 647 & 0.739 & & & \\
\hline & Total & 481.432 & 650 & & \multirow{4}{*}{3.489} & \multirow{4}{*}{$\begin{array}{c}0.016 \\
*\end{array}$} & \multirow{4}{*}{ Sign. } \\
\hline \multirow{3}{*}{ Second axis } & Between-group & 8.912 & 3 & 2.971 & & & \\
\hline & Within-group & 550.865 & 647 & 0.851 & & & \\
\hline & Total & 559.777 & 650 & & & & \\
\hline
\end{tabular}

The results in Table (9) show no SSDs at (0.05) level in the participants' responses about the positive repercussions of the Covid-19 crisis on student RL in SUs according to different academic disciplines. However, SSDs are observed at (0.05) level in the participant responses about the negative repercussions of the Covid-19 crisis on student RL in SUs according to the different academic disciplines.

Table (10) Scheffer's test results to verify the differences amongst academic discipline groups

\begin{tabular}{|c|c|c|c|c|c|c|}
\hline \multirow[b]{2}{*}{ Axis } & \multirow[b]{2}{*}{$\begin{array}{l}\text { Academic } \\
\text { discipline }\end{array}$} & \multirow[b]{2}{*}{ Freq. } & \multirow[b]{2}{*}{$\mathbf{M}$} & \multicolumn{3}{|l|}{ Academic discipline } \\
\hline & & & & Health/Medical Scient & fic Humanitarian & $\begin{array}{l}\text { Community } \\
\text { colleges }\end{array}$ \\
\hline \multirow{4}{*}{ Second axis } & Health/Medical & 154 & 4,16 & $* *$ & $*$ & \\
\hline & Scientific & 239 & 3.19 & - & & \\
\hline & Humanitarian & 217 & 3.94 & & - & \\
\hline & $\begin{array}{l}\text { Community } \\
\text { colleges }\end{array}$ & 41 & 4.21 & & & - \\
\hline
\end{tabular}

The results in Table (10) show SSDs regarding the negative repercussions of the Covid-19 crisis on student RL in SUs at the (0.01) level between participants from health/medical and scientific disciplines. 
Similarly, SSDs are observed at the (0.05) level between the participants from health/medical and humanitarian disciplines. Both results show higher scores from health/medical students.

Third: Differences according to University

Table (11) Results of one-way ANOVA for differences in participant responses due to University

\begin{tabular}{llllllll}
\hline Axes & Source of variation & SS & DF & MS & F Value & Sig. & \\
\hline \multirow{3}{*}{ First axis } & Between-group & 74.933 & 4 & 18.733 & 29.770 & $0.000^{* *}$ & Sign. \\
& Within-group & 406.499 & 646 & 0.629 & & & \\
& Total & 481.432 & 650 & & & & \\
\multirow{2}{*}{ Second axis } & Between-group & 110.331 & 4 & 27.583 & 39.645 & $0.000^{* *}$ & Sign. \\
& Within-group & 449.446 & 646 & 0.696 & & & \\
\hline
\end{tabular}

**Significance at the 0.01 level

The results in Table (11) clearly show that no SSDs are observed at (0.01) level in the participant responses regarding the positive and negative repercussions of the Covid-19 crisis on student RL in SUs according to the different universities. Scheffer' test is also used to determine whether the differences amongst the universities are in favour to any group. Table (12) shows the results.

Table (12) Scheffer's test results to verify the differences amongst universities

\begin{tabular}{|c|c|c|c|c|c|c|c|c|}
\hline \multirow{2}{*}{ Axis } & \multirow{2}{*}{ University } & \multirow{2}{*}{ Freq. } & \multirow{2}{*}{ M } & \multicolumn{2}{|c|}{ University } & \multirow[b]{2}{*}{ KKU } & \multirow[b]{2}{*}{ KAU } & \multirow[b]{2}{*}{$\mathrm{UH}$} \\
\hline & & & & KSU & KFU & & & \\
\hline \multirow{5}{*}{ First axis } & KSU & 149 & 3.96 & - & & & & \\
\hline & KFU & 127 & 4.75 & $* *$ & - & $* *$ & $* *$ & \\
\hline & KKU & 133 & 3.89 & & & - & & \\
\hline & KAU & 142 & 3.70 & & & & - & \\
\hline & UH & 100 & 4.50 & $* *$ & & $* *$ & $* *$ & - \\
\hline \multirow{5}{*}{ Second axis } & KSU & 149 & 3.80 & - & & & & \\
\hline & KFU & 127 & 4.48 & $* *$ & - & $* *$ & $* *$ & \\
\hline & KKU & 133 & 3.35 & & & - & & \\
\hline & KAU & 142 & 4.07 & & & & - & \\
\hline & UH & 100 & 4.43 & $* *$ & & $* *$ & $* *$ & - \\
\hline
\end{tabular}

** Significance at 0.01 level

\section{Discussion}

The current study aims to reveal whether there will be positive and negative impacts of the COVID19 crisis on students' remote learning in Saudi universities. To do this, a questionnaire has been given to a cluster sample of 651 undergraduate students. Results of the first question indicate that the students of SUs strongly agree with the positive repercussions of the Covid-19 crisis on their RL. The reason is the effective responses of SUs to the situation imposed by the Covid-19 crisis and to the rapid measures taken through the transition to RE. The repercussions are reflected in student learning and lead to positive changes in their academic behaviour. This finding is consistent with those of the ESN and IAU (2020) joint study that the higher education sector demonstrates a reactivity to find solutions to the effects of the pandemic, and to continue teaching and learning, which reflect positively in this 
sector's student learning. This result is also in accordance with Aristovnik, et al. (2020) that universities have a positive role during the emerging Covid-19 crisis.

The most prominent positive repercussions of the Covid-19 crisis on student RL in SUs are reflected by the phrases $(14,7,8,5,1,13)$, to which the participants strongly agree. This study focuses on the first three statements in descending order according to the values of their arithmetic means for interpretation.

Phrase No (14) ranks first, with an arithmetic mean of 4.33 (out of 5). This result is explained by SUs playing a major role during the Covid-19 crisis in caring for students' health and safety as the top priorities before their education. This result is consistent with those of Sahu (2020). Phrase No (7) ranks second, with an arithmetic mean of 4.26 (out of 5). This result is explained by the fact that the Covid-19 crisis imposed on SUs to adopt RE through the electronic platforms that provide students with the possibility to record virtual lectures, which allows them to review lectures at a convenient time and helps them stay updated. This result is consistent with those of Armstrong et al (2020). Phrase No (8) ranks third, with an arithmetic mean of 4.26 (out of 5). This result is in accordance with those of Armstrong et al. (2020), which indicate that the synchronous style of RE during the Covid-19 crisis provides students with more time to complete their academic assignments.

Concerning the second research question, result is consistent with that of Onyema et al (2020), which indicates that the emerging Covid-19 has harmful effects on education. The results are attributed to the Covid-19 crisis and its impositions on SUs to take quick and critical decisions to transit to RE, which results in new negative situations and affect the various entities involved, including students and their RL. In addition, the study participants are strongly agreeing with the 19 phrases of the negative repercussions of the Covid-19 crisis on their RL in SUs. These phrases, in descending order according to the arithmetic mean value of each, are $(13,4,5,7,15,17,14,11,1,12,8,2,6,3,19,9,10,16,18)$.

This study focuses on the most prominent of these negative repercussions, which are six phrases with the highest values of arithmetic means, although they all fall into the fourth category of the 5-point scale (3.41-4.20). The values of the arithmetic means for the first three phrases range between (4.184.14), and the next three phrases range between (4.08-4.04). This study focuses on the first three statements, $(13,4,5)$, in descending order according to the values of their arithmetic means for interpretation.

Phrase No (13) ranks first, with an arithmetic mean of 4.18 (out of 5). This result is consistent with that of Bao (2020) that student anxiety about RE during the Covid-19 crisis needs to be relieved in a positive way. In addition, the results agree with ESN and IAU (2020) and Aristovnik et al. (2020) that the anxiety of university students is mainly about their future professional career and study issues. This result is attributed to the element of surprise for the Covid-19 crisis, the pressure of time and the rapid procedures to transition to RE to reduce the crisis's harm to education, which negatively affects its progress and led to behavioural changes amongst students, such as stress and anxiety, during their RL.

Phrase (4) ranks second, with an arithmetic mean of 4.15. This result is consistent with those of Onyema et al. (2020). The reason is that the isolation and quarantine measures imposed by the Covid19 crisis on universities caused the closure of campuses, which limited student access to the required teaching and research facilities and laboratories.

Phrase No (5) ranks third, with an arithmetic mean of 4.13. This result is consistent with those of Armstrong et al. (2020) and Aristovnik et al. (2020) that the transition to virtual classes imposed on universities due to the Covid-19 crisis leads to an increase in academic workload for the students. This 
result is attributed to the new forms of assignments that have been added due to a remote method of education.

Result of the current study is consistent with that of Aristovnik et al. (2020), that the Covid-19 pandemic has a stronger overall effect on male undergraduate students. This result is attributed to repercussions imposed by the Covid-19 crisis on universities such as transition to RE, closure, staying at home, increase in social roles within the family for males and the increased family responsibility burden in comparison to before the pandemic, which reflect negatively on their RL. Although, despite the increase in family burden on male students, other members share the largest part of these burdens. Thus, students gain greater freedom and allowed them to respond positively to this sudden change imposed by the Covid-19 crisis on the university education pattern and to attain positive repercussions of this change on their RL.

In regard to the students' responses with different disciplines, result is consistent with that of Aristovnik et al. (2020) that the Covid-19 pandemic has a stronger overall impact on applied sciences students compared with their peers. This result is the fact that these majors require the actual attendance of students to universities for practice and trainings.

\section{Conclusion}

Distance learning has become a must during the Covid-19 crisis to save students from the pandemic. Distance learning is a safe alternative to face-to-face methods where students come to traditional classrooms to receive learning and teaching. Examining student attitudes is indispensable to see whether they form positive or negative views towards online learning. Results suggest that students appreciate the roles played by their institutions to ensure a safe environment by providing alternative channels to interact with their teachers and receive complete learning and teaching. Recorded lectures are found beneficial to consult anytime, given that this feature is not available in traditional classrooms. However, students express their concerns about network connections, dense assignments and absence of carrying out experiments in laboratories for those who study scientific majors.

\section{Recommendations}

1- Help faculty members in universities to alleviate student anxiety regarding their academic conditions during their distance learning in a positive way; generally, help them deal with stress and psychological and academic pressures; and support and sympathise with them.

2- University students must be able to physically attend education and research facilities and laboratories in a healthy and safe manner whilst all preventive precautions are taken for Covid-19.

3- During RL, remind faculty members in universities to avoid overburdening students with numerous tasks and assignments associated with academic courses in terms of the amount and frequency; and rather focus on those that measure real learning amongst students to develop their critical thinking, metacognitive and communication skills.

\section{Proposals for future studies}

1- Carry out a comparative study for repercussions of the coronavirus crisis on student RL in public and private SUs

2- Carry out future studies on ways to support university students during future epidemic or emerging crises 


\section{References}

References are listed in alphabetical order. Each listed reference is cited in text, and each text citation is listed in the References. References should be in line with APA 6 (American Psychological Association) style. You can reach to APA 6 standard from following link: http://owl.english.purdue.edu/owl/resource/560/01/

\section{An example appendix}

Authors including an appendix section should do so after References section. Multiple appendices should all have headings in the style used above. They will automatically be ordered A, B, C etc.

\section{A.1. Example of a sub-heading within an appendix}

There is also the option to include a subheading within the Appendix if you wish.

\section{References}

Abu al-Khair, K. (2020). Between Corona and 2009: Features of Change of Crises Management in the Age of Globalization (in Arabic). Retrieved on 03/08/2020 from: https://cutt.ly/kjFDoBS

Al Khati, M. (2020). E-learning challenges in light of the Corona crisis and beyond, Al-Jazeera Media Network, Retrieved 6 December 2020, https://www.aljazeera.net/opinions/2020/4/15

Al-Bar, A, A. (2013). Psychosocial support after the crisis (in Arabic). The First Saudi International Conference on Crisis and Disaster Management: entitled Crises and Disasters ..... Reality and Confrontation, from 2-3 / 11/1434 AH. Deanship of Community Service \& Continuing Education, Imam Muhammad bin Saud Islamic University, 18-31.

Al-Shaalan. F. A. (2013). Crisis management: foundations - phases - mechanisms (in Arabic). (3 ${ }^{\text {rd }}$ ed.), Naif Arab University for Security Sciences.

ALECSO. (2020). Let's Learn (in Arabic). ALECSO initiative for e-learning in corona crisis period. Retrieved 3/9/2020 at the link: https://www.alecso.org/elearning/ar

Al-Maghribi, M. (2019). Crisis and disasters management (in Arabic).

Al-Yousifi, R. (2005). A suggested proposal for crisis management in general secondary education schools in the Syrian Arab Republic in light of global experiences (in Arabic). Unpublished PhD thesis, Damascus University, College of Education, Syrian Arab Republic.

Al-Hurra Online Newspaper (2020). World Health announces Corona the worst crisis, (Sunday 3/15/2020), retrieved 4/8/2020 from: http://arbne.ws/3c3c3Jx

Aristovnik, A., Keržič, D., Ravšelj, D., Tomaževič, N., \& Umek, L. (2020). Impacts of the COVID-19 Pandemic on Life of Higher Education Students: A Global Perspective. Sustainability, 12(20), 8438. doi: 10.3390/su12208438

Armstrong-Mensah, E., Ramsey-White, K., Yankey, B., \& Self-Brown, S. (2020). COVID-19 and Distance Learning: Effects on Georgia State University School of Public Health Students. Frontiers In Public Health, 8. doi: 10.3389/fpubh.2020.576227

Bao, W. (2020). COVID -19 and online teaching in higher education: A case study of Peking University. Human Behavior and Emerging Technologies, 2(2), 113-115. doi: 10.1002/hbe2.191

Brodeur, A., Clark, A. E., Fleche, S., \& Powdthavee, N. (2021). COVID-19, lockdowns and well-being: Evidence from Google Trends. Journal of public economics, 193, 104346. 
Cambridge Dictionary, Meaning of implication in English, Cambridge Academic Content Dictionary, Cambridge $\begin{array}{lllll}\text { University } & \text { Press. } & \text { Retrieved } 6 \text { August } & \end{array}$ https://dictionary.cambridge.org/dictionary/english/implication?q=implicationsn

Cho, M. H., Cheon, J., \& Lim, S. (2021). Preservice teachers' motivation profiles, self-regulation, and affective outcomes in online learning. Distance Education, 42(1), 37-54.

Cooper, T. (2007). Decision making in a crisis. Journal of Police Crisis Negotiations, 7(2), 5 - 28.

Frueh, S. (2020). Facing a Future Shaped by COVID-19: How Public Universities Are Handling the Crisis, Retrieved 6 December 2020, from https://www.nationalacademies.org/news/2020/06/facing-a-future-shaped-bycovid-19-how-public-universities-are-handling-the-crisisn

Egielewa, P., Idogho, P. O., Iyalomhe, F. O., \& Cirella, G. T. (2021). COVID-19 and digitized education: Analysis of online learning in Nigerian higher education. E-Learning and Digital Media, 20427530211022808.

Greene, G. J., Lee, M., Trask, R., \& Rheinscheld, J. (2000). How to work with clients' strengths in crisis intervention. In A. R. Roberts (Ed.), Crisis intervention handbook: Assessment, treatment and research. Oxford University Press. (pp.31-55).

IAU \& ESN's joint paper on COVID-19 impact on HE: Institutional and (...) - IAU. (2020). Retrieved 6 December 2020, from https://iau-aiu.net/COVID-19-impact-on-Higher-Education-Institutional-and-Students-Perspectivesn

International Association of Universities (IAU). (2020). COVID-19: Higher Education challenges and responses, the Global Voice of Higher Education. Retrieved 6 December 2020, from https://www.iau-iau.net/COVID-19Higher-Education-challenges-and-responses

IESALC. (2020). COVID-19 and higher education: Today and tomorrow: Impact analysis, policy responses and recommendations, UNISCO, Retrieved 6 December 2020, from http://www.iesalc.unesco.org/en/wpcontent/uploads/2020/05/COVID-19-EN-130520.pdf

King Saud bin Abdulaziz University for Health Sciences (2020). The Operational Plan to Confront the Novel Corona Coved-19 (in Arabic). KSU Vice Presidency for Development and Quality in cooperation with the Preventive Medicine and Infection Control Program, and the General Administration for Social Relations and Media Affairs (without a publication number).

MOE (2019). The Operational Plan for Universities and the MOE Educational Institutions to Combat Covid-19, KSA (in Arabic). Publications of the MOE.

Lin, C. L., Jin, Y. Q., Zhao, Q., Yu, S. W., \& Su, Y. S. (2021). Factors influence students' switching behavior to online learning under COVID-19 pandemic: A push-pull-mooring model perspective. The AsiaPacific Education Researcher, 30(3), 229-245.

$\mathrm{MOH}$, KSA (2019). Corona Covid-19 health awareness (in Arabic). Retrieved on 04/09/2020 from: https://www.moh.gov.sa/HealthAwareness/EducationalContent/Corona/Pages/corona.aspx

O'Hagan, C. (2020). UNESCO rallies international organizations, civil society and private sector partners in a broad Coalition to ensure \#Learning Never Stops. Retrieved 6 December 2020, from https://en.unesco.org/news/unesco-rallies-international-organizations-civil-society-and-private-sectorpartners-broadn

Onyema, M, E., Chika E, N., Ayobamidele O, F., Sen, S., Grace A, F., S, A., \& Omar A, A. (2020). Impact of Coronavirus Pandemic on Education. Journal Of Education and Practice, 11(13). doi: 10.7176/jep/11-13-12

Quacquarelli Symonds (QS), (2020). The Impact of the Coronavirus on Global Higher Education: Excusive Qs Survey data reveals how prospective international students and higher education Institutions are responding to this global healths emergency. Retrieved 6 December 2020, from https://info.qs.com/rs/335-VIN535/images/The-Impact-of-the-Coronavirus-on-Global-Higher-Education.pdf. 
Al-Qahtani, N., Al-Salem, W. (2021). Repercussions of Covid-19 crisis on students' remote learning in Saudi universities. World Journal on Educational Technology: Current Issues. 13(4), 651-671. https://doi.org/10.18844/wjet.v13i4.6251

Raosoft (2004). Sample Size calculator, http://www.raosoft.com/samplesize.htmln .

Sahu, P. (2020). Closure of Universities Due to Coronavirus Disease 2019 (COVID-19): Impact on Education and Mental Health of Students and Academic Staff. Cureus. doi: http:doi10.7759/cureus.7541

Witze, A.(2020). Universities will never be the same after the coronavirus crisis. Retrieved 6 December 2020, from https://www.nature.com/articles/d41586-020-01518-y?fbclid=IwAR1Nnywtiys4Xs2MVGMJu2TbDSzV9StwSBMyS-oeoMV05f9hd87LdXHMfsn 